\title{
Effectiveness of passive ultrasonic irrigation on calcium hydroxide removal with different solutions
}

\section{Efetividade da irrigação ultrassônica passiva na remoção de hidróxido de cálcio com diferentes soluções}

\author{
Carina Michelon* \\ Mariana de Carlo Bello* \\ Pauline Mastella Lang* \\ Rafael Pillar ${ }^{* *}$
}

Anna Gabriela Silveira Bech ${ }^{* *}$ Carlos Alexandre Souza Bier ${ }^{* * *}$

\begin{abstract}
Objective: this study aimed to assess the effectiveness of Passive Ultrasonic Irrigation (PUI) with different solutions for calcium hydroxide $\left(\mathrm{Ca}(\mathrm{OH})_{2}\right)$ removal. Materials and method: forty-eight single-rooted mandibular premolars were prepared and filled with $\mathrm{Ca}(\mathrm{OH})_{2}$. After 15 days, the specimens were randomly divided into four groups according to the method of removal of the intracanal medication ( $n=12)$. In Group 1, $\mathrm{Ca}(\mathrm{OH})_{2}$ removal was performed through conventional irrigation with $2.5 \% \mathrm{NaOCl}$ and $17 \%$ EDTA combined with the use of the 'master apical file' at working length. Groups 2 and 3 were treated in the same manner as Group 1, following the PUI with $2.5 \% \mathrm{NaOCl}$ and $17 \%$ EDTA, and $2.5 \% \mathrm{NaOCl}$ and $10 \%$ citric acid, respectively. Group 4 served as a control group and received no intracanal medication. The roots were longitudinally grooved and split in two halves. The half with the higher remaining amount was analyzed with a stereomicroscope, and the percentage of surface area covered by the remaining $\mathrm{Ca}(\mathrm{OH})_{2}$ in relation to the total surface area and the surface area of each third of the root canal was calculated. The results were statistically analyzed with the Kruskal-Wallis Test and Mann-Whitney Test. Null hypothesis was set as 5\%. Results: none of the groups tested showed similarity to the control group $(P<0.05)$.
\end{abstract}

However, no statistical difference was observed between the removal techniques of $\mathrm{Ca}(\mathrm{OH})^{2}$ from root canals. Conclusions: neither syringe irrigation nor the combination of syringe irrigation with PUI were effective methods for removing $\mathrm{Ca}(\mathrm{OH})^{2}$ from the root canals.

Keywords: Calcium hydroxide. Ultrasound. Citric acid. Irrigation. Root canal.

\section{Introduction}

The reduction or elimination of bacteria and their byproducts from the root canal system is one of the main objectives of root canal treatment ${ }^{1}$. Intracanal medication with strong antibacterial activity against most of the bacterial strains identified in root canal infections is used in order to improve disinfection of the root canal ${ }^{2}$. The most commonly used intracanal medication is calcium hydroxide $\left(\mathrm{Ca}(\mathrm{OH})_{2}\right)$ due to its effectiveness against the majority of endodontic pathogens and its biocompatibility ${ }^{3}$.

\footnotetext{
Master in Dental Science from Santa Maria Federal University, Santa Maria, RS, Brazil.

Graduated from Santa Maria Federal University, Santa Maria, RS, Brazil.

Professor, PhD, Discipline of Endodontics, Department of Stomatology, Santa Maria Federal University, Santa Maria, RS, Brazil.
} 
However, $\mathrm{Ca}(\mathrm{OH})_{2}$-based medication should be removed before root filling ${ }^{4}$ because $\mathrm{Ca}(\mathrm{OH})_{2}$ residue on the canal walls negatively affects the quality of the root filling ${ }^{5,6}$. Furthermore, remnants of $\mathrm{Ca}(\mathrm{OH})_{2}$ influence dentine bond strength ${ }^{6-8}$, interfere with the sealing ability ${ }^{7-10}$, and prevent the penetration of sealers into dentinal tubules, resulting in a potential reduction of sealer adaptation ${ }^{11}$.

The removal of $\mathrm{Ca}(\mathrm{OH})_{2}$ residue from irregular canal walls is difficult ${ }^{12}$. Various products and techniques were described. The most common method for removing $\mathrm{Ca}(\mathrm{OH})_{2}$ is the use of a 'master apical file' (MAF) at working length combined with copious sodium hypochlorite $(\mathrm{NaOCl})$ and ethylenediaminetetraacetic acid (EDTA) ${ }^{13-15}$ irrigation. With the addition of EDTA, the citric acid has also been tested. According to Rödig et al. ${ }^{16}$ (2010), citric acid and EDTA showed better results than $\mathrm{NaOCl}$ and water. Moreover, the combination of chelating agents and $\mathrm{NaOCl}$ did not lead to significant improvement in calcium hydroxide removal.

Nevertheless, canal irregularities may be inaccessible for conventional irrigation procedures, and $\mathrm{Ca}(\mathrm{OH})_{2}$ may remain in these extensions ${ }^{17}$. The passive ultrasonic irrigation (PUI) is effective in dentine debris removal from the root canal walls ${ }^{18-20}$ and in removing $\mathrm{Ca}(\mathrm{OH})_{2}$ paste from the root ca$\mathrm{nal}^{21,22}$. Saline solution, water, $\mathrm{NaOCl}, \mathrm{EDTA}$, and combinations thereof, have been used as irrigation material during PUI. To this date, no study in literature assesses the use of PUI with citric acid for of $\mathrm{Ca}(\mathrm{OH})_{2}$ removal.

Thus, this study aims to assess the effectiveness of PUI with $\mathrm{NaOCl}$ and different chelating solution after the use of 'master apical file' for $\mathrm{Ca}(\mathrm{OH})_{2}$ removal in oval canals.

\section{Materials and method}

This study was submitted and approved by the Ethical Committee of the Federal University of Santa Maria (CAAE: 08509712.7.0000.5346).

\section{Tooth selection}

Forty-eight single-rooted mandibular premolar teeth with complete root formation, straight root, and oval cross-section of the roots were selected and stored in distilled water until use. Radiographs in the mouth-lingual and mesial-distal directions were taken and the canal was identified as oval when the mouth-lingual diameter was $\geq 2$ of the mesiodistal diameter. The curvature angle of the root canal was measured following Schneider's methodology ${ }^{23}$.

\section{Cleaning and shaping}

Coronal access was performed using 1014 diamond burs and Endo-Z burs (KG Sorensen, Cotia, SP, Brazil) in water-cooled, high-speed handpiece. The clinical crown was not removed in order to allow a greater amount of irrigating solution in contact with the channel walls. The canal patency was established with a size $10 \mathrm{~K}$-file (Dentsply Maillefer, Ballaigues, Switzerland). A size $15 \mathrm{~K}$-file (Dentsply Maillefer) was placed into the canal until visible at the apical foramen. The working length (WL) was determined by subtracting $1 \mathrm{~mm}$ from this measurement.

Root canals were prepared with ProTaper rotating instruments (Dentsply Maillefer) by using a torque-control X-Smart motor (Dentsply Maillefer) rotating at $300 \mathrm{rpm}$. Initially, the cervical and middle thirds of the roots were prepared using S1, SX and S2 instruments. Later, S1, S2, F1, F2, and F3 files were sequentially used for the entire WL. Each canal was irrigated with $3 \mathrm{~mL}$ of a freshly prepared $2.5 \% \mathrm{NaOCl}$ solution between each instrument change. To ensure that the apical diameter was uniform after preparation, a size $30 \mathrm{~K}$-file, 0.02 taper (Dentsply Maillefer) was inserted through the entire WL. After conclusion of instrumentation, the PUI was performed with $2.5 \% \mathrm{NaOCl}$ and $17 \%$ EDTA with a size $15 \mathrm{~K}$-file, 0.02 taper (Dentsply Maillefer) in order to effectively clean the canals and remove remaining debris ${ }^{21}$. The roots were subsequently rinsed with $2 \mathrm{~mL}$ of distilled water. The canals were aspirated with Capillary Tips (Ultradent; Munich, Germany), and dried using size 30 paper points (Dentsply Maillefer).

The $\mathrm{Ca}(\mathrm{OH})_{2}$ paste (Calen, SS White, Rio de Janeiro, Brazil) was placed into the entire WL with a screwable syringe (Duflex, SS White, Rio de Janeiro, Brazil). A radiograph was taken to confirm the complete filling of the canal. The access cavities were temporarily sealed with a cotton pellet and Cavit (Espe, Seefeld, Germany) down to a depth of $2 \mathrm{~mm}$. The roots were then placed in a sponge saturated with natural water and incubated in $100 \%$ relative humidity at $37^{\circ} \mathrm{C}$ for 15 days. After this period, the temporary filling material was removed using 1012 diamond burs (KG Sorensen) in water-cooled, high-speed handpiece. The medication was removed from all canals initially with $8 \mathrm{ml}$ of $2.5 \%$ $\mathrm{NaOCl}$, alternating with a size $30 \mathrm{~K}$-file (Dentsply Maillefer) inserted in the WL with an oscillatory motion. The specimens were randomly assigned by a Random Allocation Software program (Microsoft, Washington, United States) to 3 experimental groups $(\mathrm{n}=12)$, according to the $\mathrm{Ca}(\mathrm{OH})_{2}$ removal technique. The control group $(n=12)$ received no intracanal medication (Table 1). 
Table 1 - Experimental groups according to irrigation material and irrigation technique.

\begin{tabular}{l|r|r|r}
\hline Group & $\mathrm{n}$ & Irrigant & Irrigation Technique \\
\hline 1 & 12 & $\mathrm{NaOCl}+$ EDTA & $\begin{array}{r}\text { Conventional } \\
\text { Irrigation }\end{array}$ \\
2 & 12 & $\mathrm{NaOCl}+$ EDTA & PUI \\
3 & 12 & $\mathrm{NaOCl}+$ Citric Acid & PUI \\
4 & 12 & \\
\hline
\end{tabular}

Fonte: dos autores.

In Group 1, final irrigation was performed with $2 \mathrm{~mL}$ of $2.5 \% \mathrm{NaOCl}$ and $2 \mathrm{~mL}$ of $17 \%$ EDTA, manually agitated with a size $15 \mathrm{~K}$-file, 0.02 taper (Dentsply Maillefer) for 3 minutes with an oscillatory motion. Finally, root canals were irrigated with $2 \mathrm{~mL}$ of $2.5 \% \mathrm{NaOCl}$ to neutralize the action of the EDTA.

In Group 2, root canals were irrigated with PUI using the piezoelectric unit (Ultrasound Ultra Sonic, Gnatus, São Paulo, Brazil) with a stainless steel size $15 \mathrm{~K}$-file, 0.02 taper (Dentsply Maillefer), at high, oscillating in the vestibule-lingual direction, inserted in the root canal $2 \mathrm{~mm}$ short of the WL. Firstly, 3 activations with $2.5 \% \mathrm{NaOCl}$ were performed. Each activation lasted $20 \mathrm{~s}$, in a total of $1 \mathrm{~min}$ per canal. Between activations, the solution was replenished. Later, the $17 \%$ EDTA was activated with ultrasound for $1 \mathrm{~min}$. Finally, each canal was irrigated with $2 \mathrm{ml}$ of $2.5 \% \mathrm{NaOCl}$ to neutralize the action of the EDTA.

In Group 3, the PUI was employed the same manner as described for group 2, but citric acid was used instead of the EDTA.

After each technique, the canals were aspirated with Capillary Tips (Ultradent), and dried using size 30 paper points (Dentsply Maillefer). The crowns of the teeth were removed using a cylindrical diamond bur (KG Sorensen) in a high-speed handpiece, under constant water spray. Longitudinal grooves with $2 \mathrm{~mm}$ deep were cut on the bucco and lingual root surfaces without damaging the inner dentine layer around the canal using a double-sided diamond disc (KG Sorensen), and split into halves using a chisel.

\section{Evaluation of calcium hydroxide percentage}

The root half with the largest amount of remaining $\mathrm{Ca}(\mathrm{OH})_{2}$ was chosen and viewed through a $10 \mathrm{x}$ stereomicroscope using a cold light source (Zeiss Stemi SV6; Carl Zeiss, Jena, Germany). Pictures were taken, saved in tiff format and analyzed by a single blinded examiner who had previously been calibrated for the measuring procedure. The same observer read the stereomicroscopies images twice with a 1-week interval between readings. The amount of residual $\mathrm{Ca}(\mathrm{OH})_{2}$ on the canal walls was measured in $\mathrm{mm}^{2}$ using the AxioVision Program (Zeiss, Gottingen, Germany) and recorded as a percentage of the surface area of each third of the root canal (Fig. 1).

\section{Statistical analysis}

The Kruskal-Wallis test was used to compare the percentage of remaining $\mathrm{Ca}(\mathrm{OH})_{2}$ among groups, for each third and considering the canal as a whole. The Mann-Whitney test was performed as the post hoc multiple comparison method. The General Linear Model was used to compare the amount of remaining $\mathrm{Ca}(\mathrm{OH})_{2}$ between thirds of the same group. The significance level was set at $\alpha=0.05$. Statistical analysis was performed with SPSS Statistics 18 software (SPSS Inc., Chicago, IL, USA).

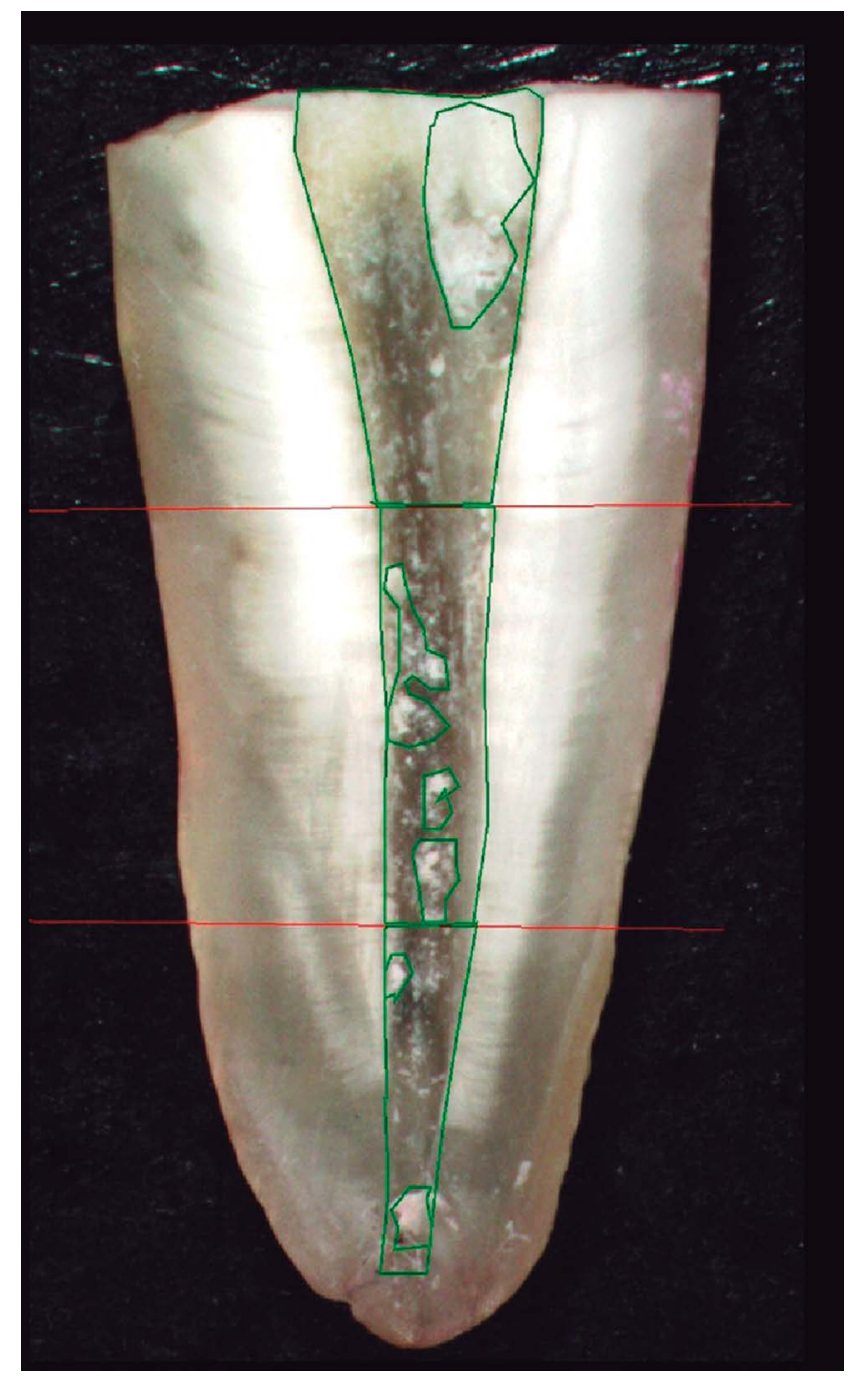

Figure 1 - Image of $\mathrm{Ca}(\mathrm{OH})_{2}$ remaining on the root canal walls and the calculation of the area of $\mathrm{Ca}(\mathrm{OH})_{2}$, using an imaging program

\section{Results}

Table 2 shows percentages of remnants of $\mathrm{Ca}(\mathrm{OH})_{2}$ in each group, for the thirds and for the canal as a whole. Remnants of medication were 
found in all experimental groups regardless of the removal technique. No significant differences were observed between experimental groups $(P>0.05)$. However, none of the tested groups showed simila- rities to the control group $(P<0.05)$. When the percentage of residual $\mathrm{Ca}(\mathrm{OH})_{2}$ was compared between thirds into same group, no significant difference was found $(P>0.05)$.

Table 2 - Percentage of remaining residual $\mathrm{Ca}(\mathrm{OH})_{2}$ in the canal [mean and standard deviation (SD)]

\begin{tabular}{|c|c|c|c|c|}
\hline \multirow{2}{*}{ GROUP } & \multicolumn{4}{|c|}{ Mean $(\%) \pm$ Standard Deviation } \\
\hline & Cervical & Middle & Apical & Total \\
\hline $\mathrm{NaOCl}+\mathrm{EDTA}$ & $12.25 \pm 14.99$ & $8.24 \pm 13.42$ & $13.63 \pm 14.27$ & $11.37 \pm 10.48$ \\
\hline $\mathrm{PUI} / \mathrm{NaOCl}+\mathrm{EDTA}$ & $2.32 \pm 4.8$ & $8.30 \pm 19.64$ & $12.35 \pm 24.20$ & $7.66 \pm 13.79$ \\
\hline PUI/ $\mathrm{NaOCl}+$ Citric Acid & $3.32 \pm 8.37$ & $3.93 \pm 11.88$ & $9.52 \pm 14.50$ & $5.59 \pm 8.69$ \\
\hline Control & 0 & 0 & 0 & 0 \\
\hline
\end{tabular}

Fonte: dos autores.

\section{Discussion}

In this study, complete removal of $\mathrm{Ca}(\mathrm{OH})_{2}$ from the canal walls was not attained under the tested conditions, and remnants of $\mathrm{Ca}(\mathrm{OH})_{2}$ were found in all experimental groups. This result is similar to the results of previous studies, which showed considerable amounts of $\mathrm{Ca}(\mathrm{OH})_{2}$ on the canal walls, regardless of the removal technique used ${ }^{4,13,21,22,24,25}$.

Furthermore, complementation with the PUI presented no significant improvement in the removal of $\mathrm{Ca}(\mathrm{OH})_{2}$. This may be explained by the fact that all groups were previously irrigated with $\mathrm{NaO}$ $\mathrm{Cl}$ and instrumented in WL with a file of oscillatory movements. Balvedi et al. ${ }^{26}$ (2010), using a similar method to that of this study, also observed that there was no significant difference in the removal of $\mathrm{Ca}(\mathrm{OH})_{2}$ between the action of a MAF with copious irrigation and its association with the PUI. However, these results diverge from results obtained by van der Sluis et al. ${ }^{17}$ (2007), which showed that the PUI with $2 \% \mathrm{NaOCl}$ was more effective in removing $\mathrm{Ca}(\mathrm{OH})_{2}$ paste from artificial root canal grooves than either syringe delivery of $\mathrm{NaOCl}$ or water as irrigant. The methodological difference between the studies may explain the discrepancy in results, as van der Sluis et al. ${ }^{17}$ (2007) did not use a file concomitantly with manual irrigation, which differs from this research.

The PUI is based on the transmission of energy from an ultrasonic oscillating instrument to the irrigant inside the root canal ${ }^{27}$. It has been shown that the irrigation material, combined with ultrasonic vibration, is directly associated with the removal of organic and inorganic debris from the root canal walls $^{21,25}$. Thus, considering that the effectiveness of irrigation could depend on both the mechanical flushing action and the chemical irrigation capability, an attempt was made in the present study to verify the action of the PUI with chelating solutions. EDTA and citric acid are chelating solutions capable of dissolving inorganic particles due to their pro- perty of reacting with calcium ions in dentine and forming soluble calcium chelates ${ }^{28}$. This property justifies the results of Chalt e Serper ${ }^{11}$ (1999) that showed complete removal of $\mathrm{Ca}(\mathrm{OH})_{2}$ from the root canal after irrigation with EDTA followed by Na$\mathrm{OCl}$ in comparison to $\mathrm{NaOCl}$ alone. Rodig et al. ${ }^{16}$ (2010) had already associated chelating solutions with the PUI and attained better results with citric acid and EDTA in the removal of $\mathrm{Ca}(\mathrm{OH})_{2}$ in comparison to $\mathrm{NaOCl}$. In this study, the best results were observed in the groups with chelating solutions and PUI (Groups 2 and 3), and the lowest average in the group using the citric acid as irrigation material (Group 3), although with no significant statistical difference $(p>0.05)$.

The inexistence of statistical difference between the groups in this study may be partially attributed to the high standard deviation values. The sample was composed of teeth with oval root canals, which may hinder cleaning and lead to discrepant values of remaining $\mathrm{Ca}(\mathrm{OH})_{2}$ in the experimental groups, thus providing high standard deviation values. Even when a big difference is observed in the mean percentage of remaining $\mathrm{Ca}(\mathrm{OH})$, between the groups, a high standard deviation may mask a possible statistical difference. Although the authors of this study have standardized the selection of specimens as much as possible, premolar teeth have shown great anatomical complexity ${ }^{29}$, which often cannot be verified through radiographic examination used during teeth selection.

Although no statistically significant difference was observed among the groups, regarding the thirds a reduction of remaining $\mathrm{Ca}(\mathrm{OH})_{2}$ was observed in the cervical third, which may be explained by the action mechanism of PUI. On the other hand, the apical third had higher amounts of remaining $\mathrm{Ca}(\mathrm{OH})_{2}$ even using the PUI. This may be explained due to the reduced enlargement of apical third (\#30), which may have influenced the amplitude of oscillation of the instrument in the PUI ${ }^{30}$. In relation to the middle third, further reduction of $\mathrm{Ca}(\mathrm{OH})_{2}$ was 
observed in Group 3. This fact may be associated with anatomical difference in this third.

Different methodologies have been used to assess the amount of $\mathrm{Ca}(\mathrm{OH})_{2}$ remaining ${ }^{22,31,32}$. In the present study, the specimens were longitudinally split, and the percentage of residual $\mathrm{Ca}(\mathrm{OH})_{2}$ was calculated from images obtained under magnification of the entire area desired at stereomicroscopy. Four different aspects of the tooth were assessed: the apical, middle, and coronal thirds, as well as the entire canal. This method has been reported as effective in determining the amount of $\mathrm{Ca}(\mathrm{OH})_{2}$ residue and minimized subjectivity in the scoring method based on a scale ${ }^{16}$. The assessment of the remaining $\mathrm{Ca}(\mathrm{OH})_{2}$ could have been performed using scanning electron microscopy (SEM) ${ }^{32,33}$. However, as the aim was not to evaluate small areas and the opening of dentinal tubules, SEM was not used. Recently, micro-computed tomography has been used to assess the efficacy of different techniques of $\mathrm{Ca}(\mathrm{OH})_{2}$ removal. However, access to the equipment needed for this kind of assessment is limited ${ }^{22,34}$.

Considering that many of the samples showed remnants of $\mathrm{Ca}(\mathrm{OH})_{2}$, further research is necessary in order to elucidate irrigation protocols for removal of intracanal medication before final filling of the root canal to reduce side effects and optimize the benefits of $\mathrm{Ca}(\mathrm{OH})_{2}$ in endodontic treatment.

\section{Conclusion}

Within the limitations of this study, no technique was able to completely remove $\mathrm{Ca}(\mathrm{OH})_{2}$ from the oval root canals. The association of 'master apical file' with the PUI using $\mathrm{NaOCl}$ and chelating solutions for removing $\mathrm{Ca}(\mathrm{OH})$, showed similar results. Any of the techniques is suggested, since all of them were equally effective in removing $\mathrm{Ca}(\mathrm{OH})_{2}$.

\section{Resumo}

Objetivo: o objetivo deste estudo foi avaliar a efetividade da irrigação ultrassônica passiva (IUP) com diferentes soluções para remover o hidróxido de cálcio $\left(\mathrm{Ca}(\mathrm{OH})_{2}\right)$. Materiais e método: 48 pré-molares inferiores monorradiculares foram preparados e preenchidos com $\mathrm{Ca}(\mathrm{OH})_{2}$. Após 15 dias, os espécimes foram distribuídos randomicamente em quatro grupos, de acordo com o método de remoção da medicação intracanal $(n=12)$. No Grupo 1, a remoção do $\mathrm{Ca}(\mathrm{OH})_{2}$ foi realizada, associando a irrigação convencional com NaOCl $2,5 \%$ e EDTA $17 \%$ e a lima memória no comprimento de trabalho. Os Grupos 2 e 3 foram tratados da mesma maneira que o Grupo 1, seguindo da IUP com NaO$\mathrm{Cl} 2,5 \%$ e EDTA $17 \%$, e $\mathrm{NaOCl} 2,5 \%$ e ácido cítrico $10 \%$, respectivamente. O Grupo 4 serviu como grupo controle e não recebeu qualquer medicação intracanal. As raízes foram sulcadas longitudinalmente e divididas em duas partes. A metade com a maior quantidade de remanescente foi analisada em um estereomicros- cópio, e a porcentagem de área de superfície coberta com remanescente de $\mathrm{Ca}(\mathrm{OH})_{2}$ em relação à área de superfície total e à área de superfície por terços do canal radicular foi calculada. Os resultados foram analisados estatisticamente com o teste Kruskal-Wallis e o teste Mann-Whitney. A hipótese nula foi fixada em $5 \%$. Resultados: nenhum dos grupos testados foi similar ao grupo controle $(P<0,05)$. Entretanto, não foi observada diferença estatística entre as técnicas de remoção do $\mathrm{Ca}(\mathrm{OH})_{2}$ do canal radicular. Conclusões: nem a irrigação com seringa, nem a combinação da irrigação com a seringa com IUP foram métodos efetivos para remoção do $\mathrm{Ca}(\mathrm{OH})_{2}$ do canal radicular.

Palavras-chave: Hidróxido de cálcio. Ultrassom. Ácido cítrico. Irrigação. Canal radicular.

\section{References}

1. Biströem A, Sundqvist G. Bacteriologic evaluation of the efficacy of mechanical root canal instrumentation in endodontic therapy. Scand J Dent Res 1981; 89(4):321-8.

2. Lee M, Winkler J, Hartwell G, Stewart J, Caine R. Current trends in endodontic practice: emergency treatments and technological armamentarium. J Endod 2009; 35(1):35-9.

3. Athanassiadis B, Abbott PV, Walsh LJ. The use of calcium hydroxide, antibiotics and biocides as antimicrobial medicaments in endodontics. Aust Dent J 2007; 52(sp. Issue):64-82.

4. Nandini S, Velmurugan N, Kandaswamy D. Removal efficiency of calcium hydroxide intracanal medicament with two calcium chelators: volumetric analysis using spiral CT, an in vitro study. J Endod 2006; 32(11):1097-101.

5. Caliskan MK, Turkun M, Turkun LS. Effect of calcium hydroxide as an intracanal dressing on apical leakage. Int Endod J 1998; 31(3):173-7.

6. Barbizam JV, Trope M, Teixeira EC, Tanumaru-Filho M, Teixeira FB. Effect of calcium hydroxide intracanal dressing on the bond strength of a resin-based endodontic sealer. Braz Dent J 2008; 19(3):224-7.

7. Windley W 3rd, Ritter A, Trope M. The effect of short-term calcium hydroxide treatment on dentin bond strengths to composite resin. Dent Traumatol 2003; 19(2):79-84

8. Erdemir A, Ari H, Gungunes H, Belli S. Effect of medications for root canal treatment on bonding to root canal dentin. J Endod 2004; 30(2):113-6.

9. Kim SK, Kim YO. Influence of calcium hydroxide intracanal medication on apical seal. Int Endod J 2002; 35(7):623-8.

10. Contardo L, De Luca M, Bevilacqua L, Breschi L, Di Lenarda R. Influence of calcium hydroxide debris on the quality of endodontic apical seal. Minerva Stomatol 2007; 56(7):509-17.

11. Calt S, Serper A. Dentinal tubule penetration of root canal sealers after root canal dressing with calcium hydroxide. J Endod 1999; 25(6):431-3.

12. Ricucci D, Langeland K. Incomplete calcium hydroxide removal from the root canal: a case report. Int Endod J 1997; 30(6):418-21.

13. Lambrianidis T, Margelos J, Beltes P. Removal efficacy of calcium hydroxide dressing from the root canal. J Endod 1999; 25(2):85-8.

14. Lambrianidis T, Kosti E, Boutsioukis C, Mazinis M. Removal efficacy of various calcium hydroxide/chlorhexidine medicaments from the root canal. Int Endod J 2006; 39(1):55-61.

15. Salgado RJ, Moura-Netto C, Yamazaki AK, Cardoso LN, De Moura AA, Prokopowitsch I. Comparison of different irrigants on calcium hydroxide medication removal: microsco- 
pic cleanliness evaluation. Oral Surg Oral Med Oral Pathol Oral Radiol Endod 2009; 107(4):580-4.

16. Rödig T, Vogel S, Zapf A, Hülsmann M. Efficacy of different irrigants in the removal of calcium hydroxide from root canals. Int Endod J 2010; 43(6):519-27.

17. van der Sluis LWM, Wu MK, Wesselink PR. The evaluation of removal of calcium hydroxide paste from an artificial standardized groove in the apical root canal using different irrigation methodologies. Int Endod J 2007; 40(1):52-7.

18. Gutarts R, Nusstein J, Reader A, Beck M. In vivo debridement efficacy of ultrasonic irrigation following hand-rotary instrumentation in human mandibular molars. J Endod 2005; 31(3):166-70.

19. Passarinho-Neto JG, Marchesan MA, Ferreira RB, Silva $\mathrm{RG}$, Silva-Sousa YTC, Sousa-Neto MD. In vitro evaluation of endodontic debris removal as obtained by rotary instrumentation coupled with ultrasonic irrigation Aust Endod J 2006; 32(3):123-8.

20. Rödig T, Sedghi M, Konietschke F, Lange K, Ziebolz D, Hülsmann M. Efficacy of syringe irrigation, RinsEndo and passive ultrasonic irrigation in removing debris from irregularities in root canals with different apical sizes. Int Endod $\mathrm{J}$ 2010; 43(7):581-9.

21. van der Sluis LWM, Versluis M, Wu MK, Wesselink PR. Passive ultrasonic irrigation of the root canal: a review of the literature. Int Endod J 2007; 40(6):415-26.

22. Wiseman A, Cox Timothy C, Paranjpe A, Flake NM, Cohenca N, Johnson JD. Efficacy of sonic and ultrasonic activation for removal of calcium hydroxide from mesial canals of mandibular molars: a microtomographic study. J Endod 2011; 37(2):235-8.

23. Schneider SW. A comparison of canal preparations in straight and curved root canals. Oral Surg Oral Med Oral Pathol Oral Radiol Endod 1971; 32(2):271-5.

24. Margelos J, Eliades G, Verdelis C, Palaghias G. Inter-action of calcium hydroxide with zinc oxide-eugenol type sealers: a potential clinical problem. J Endod 1997; 23(1):43-8.

25. Kenee DM, Allemang JD, Johnson JD, Hellstein J, Nichol BK. A quantitative assessment of efficacy of various calcium hydroxide removal techniques. J Endod 2006; 32(6):563-5.

26. Balvedi RPA, Versiani MA, Manna FF, Biffi JCG. A comparison of two techniques for the removal of calcium hydroxide from root canals. Int Endod J 2010; 43(9):763-8.

27. van der Sluis LWM, Wu MK, Wesselink PR. A comparison between a smooth wire and a $\mathrm{K}$ file in the removal of artificially placed dentine debris in plastic blocks. Int Endod $\mathrm{J}$ 2005; 38(9):593-6.

28. Violich DR, Chandler NP. The smear layer in endodontics a review. Int Endod J 2010; 43(1):2-15.

29. Ordinola-Zapata R, Bramante CM, Villas-Boas MH, Cavenago BC, Duarte MH, Versiani MA. Morphologic MicroComputed Tomography Analysis of Mandibular Premolars with Three Root Canals. J Endod 2013; 39(9):1130-5.

30. Boutsioukis C, Verhaagen B, Walmsley AD, Versluis M, van der Sluis LWM. Measurement and visualization of fileto-wall contact during ultrasonically activated irrigation in simulated canals. Int Endod J 2013; 46(11):1-10.

31. Zart PTM, Michelon C, Zanatta FB, Bier CAS, Manfio AP. Eficácia da irrigação ultrassônica passiva na remoção de hidróxido de cálcio. Rev Odontol UNESP 2014; 43(1):15-23.

32. Ahmetoğlu F, Simșek N, Keles A, Ocak MS, Er K. Efficacy of self-adjusting file and passive ultrasonic irrigation on removing calcium hydroxide from root canals. Dent Mat J 2013; 32(6):1005-10

33. Silva JM, Silveira A, Santos E, Prado L, Pessoa OF. Efficacy of sodium hypochlorite, ethylenediaminetetraacetic acid, citric acid and phosphoric acid in calcium hydroxide removal from the root canal: a microscopic cleanliness evaluation. Oral Surg Oral Med Oral Pathol Oral Radiol Endod 2011; 112(6):820-4.

34. Silva LJM, Pessoa OF, Teixeira MBG, Gouveia CH, Braga RR. Micro-CT evaluation of calcium hydroxide removal through passive ultrasonic irrigation associated with or without an additional instrument. Int Endod J 2014 (In Press).

\section{Corresponding author:}

Mariana De Carlo Bello

Medianeira Avenue, 1688/802

97060-002 Santa Maria-RS

Cell phone: (55) 91595503

E-mail: maridcbello@yahoo.com.br

Recebido: 22/01/2014. Aceito: 22/09/2014. 